\title{
Valinnanvapaus SOTE-uudistuksessa
}

Sosiaali- ja terveysministeriö (STM) asetti 13.I.2016 asiantuntijaryhmän (sote-asiantuntijaryhmä), jonka tehtävänä on tukea ja antaa asiantuntemustaan ja näkemyksiään sosiaali- jaa terveydenhuollon uudistuksen valmisteluryhmille. STM pyysi 9.1I.2017 asiantuntijaryhmän jäseniltä kirjallista arviota 3.II.2017 päivätystä hallituksen esitysluonnoksesta laiksi asiakkaan valinnanvapaudesta sosiaali- ja terveydenhuollossa (valinnanvapauslaki). Valtaosa sote-asiantuntijaryhmän jäsenistä päätti jättää saman sisältöisen lausunnon, jossa tuodaan esiin valinnanvapauslakiesityksen keskeiset haasteet sosiaali- ja terveydenhuollon toiminnan kannalta. Vaikka lausunnon kohteena ollutta esitysluonnosta on lausuntojen perusteella korjattu, on esityksessä edelleen useita asiantuntijalausunnoissa kuvattuja ongelmia. Tässä artikkelissa julkaistaan lausuntojen sisältö.

Terveyserojen ja sosiaalisten hyvinvointierojen kaventamiselle on selvä tarve. Valinnanvapauslain riskinä on, etteivät resurssit kohdennu palveluita eniten tarvitseville ja erot sosiaaliryhmien välillä jopa lisääntyvät. Valinnanvapaus voi parantaa niiden sosiaali- ja terveyspalveluja tarvitsevien henkilöiden asemaa, joiden toimintakyky on riittävä järjestelmän tuomien mahdollisuuksien hahmottamiseksi. Valinnanvapaus ei kuitenkaan toteudu sosiaali- ja terveydenhuollon integraation kannalta tarkoituksenmukaisella tavalla. Valinnanvapauslaki loisi asiakkaan kannalta monimutkaisen palveluiden järjestelmän, jossa palveluketjut (ainakin useampia palveluita tarvitsevilla) katkeavat.

Valinnanvapauslaki voi parantaa perustason terveyspalvelujen saatavuutta, mutta alueellisesti vaikutukset voivat olla erilaisia ja jossain jopa palvelujen saatavuutta huonontavia. Ehdotettu malli edellyttää lisäksi laajaa ja resursseja vaativaa palveluohjauksen organisoimista, koska palvelujen tarjoajan ja palvelujen käyttäjän välillä on tiedollinen epäsuhta, mikä helposti johtaa epätarkoituksenmukaisten taikka kustannusvaikutuksiltaan huonojen palvelujen valintaan.

Kokonaisuutena uudistuksen tuloksena syntyvä sosiaali- ja terveydenhuollon järjestelmä on vaikeasti ohjattava. Suomalaiset kokemukset sopimusohjauksesta eivät tue oletusta ohjausmallin tehokkuudesta kustannusten hillinnässä. Taloudellisesti kestävän tuotantotavan hakemiseen maakunnissa tuleekin menemään useita vuosia. Merkittäaät siirrot henkilöstöresursseissa yksityisen ja julkisen tuotannon välillä uudistuksen alussa voivat lisäksi vaarantaa keskeisten toimintojen (kuten päivystys) järjestämisen.

Maakuntien ja tuottajien rahoituskorvaukset tulisi suunnitella sellaiseksi, että ne kannustavat tarjoamaan palveluita niitä eniten tarvitseville. Korvausperusteilla on myös vaikutusta siihen, mille hoito- tai maantieteellisille alueille tuottajat sijoittuvat.

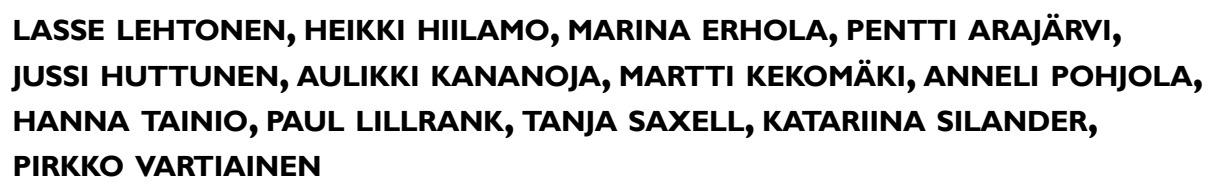




\section{JOHDANTO}

Hyvinvointi on Suomessa polarisoitunut vahvasti viimeisen lähes 30 vuoden aikana. Talousongelmista huolimatta hyvinvointi on yleisesti lisääntynyt - mitattiinpa sitä kulutusmahdollisuuksina, onnellisuuden kokemuksina tai elinikänä (1). Pitkäaikaisesta köyhyydestä kertoo se, että toimeentulotuesta on tullut yhä useammille kotitalouksille pysyvä tulonlähde (2). Kodin ulkopuolelle sijoitettujen lasten määrä on kaksinkertaistunut 1990-luvun alusta (3). Leipäjonoista on tullut osalle pysyvä osa toimeentuloa (4). Koulutus- ja tuloryhmien sosioekonomiset erot elinajanodotteessa kasvoivat kaventamiseen pyrkivistä ponnisteluista huolimatta merkittävästi vuosina 1988 2007. Erojen kasvu pysähtyi 2010-luvulla lukuun ottamatta naisten eroja koulutusryhmittäin (5). Sosiaaliset ongelmat - pitkäaikaistyöttömyys, köyhyys, lasten pahoinvointi, yksinäisyys, syrjäytyminen - kietoutuvat yhteen terveysongelmien kanssa ja siirtyvät usein sukupolvelta toiselle. Ylisukupolvista huono-osaisuutta selittää eniten vanhempien ei-materiaalisten resurssien puute (6). Ongelmien kasaantuminen alkaa jo nuoruusiässä $(7,8)$.

Suomen nykyongelmat näkyvät väestöryhmien hyvinvointi- ja terveyseroina. 1990-luvun alun laman jälkeen työmarkkinoilta syrjäytyminen loi Suomeen köyhyysongelman, joka paitsi erottaa meidät muista Pohjoismaista, korostaa tarvetta uudistaa sosiaali- ja terveyspalveluiden väestöllistä kohdentumista väestön terveys- ja hyvinvointierojen kaventamiseksi (9).

Vauraissa yhteiskunnissa, joissa terveysmenot ylittävät 2000 USD asukasta kohden ja joissa ympäristönterveyshaittoja (liikenne, ilma, työtapaturmat, jne.) on vähennetty, sosioekonomisten ryhmien terveyserojen suurimmat selittäjät ovat elintavat (terveyskäyttäytyminen) ja perimä. Palvelut ja niiden käyttö selittävät noin viidenneksen eroista. Terveyspalvelujen alikäyttö voi johtua seuraavista syistä:

- yksilö ei tiedosta omia tai läheistensä terveysongelmia eikä siksi hakeudu hoitoon: alikysyntäongelma

- yksilö tiedostaa tarpeensa, mutta hakeutuminen on vaikeaa tai kallista: saavutettavuusongelma

- yksilö hakeutuu hoitoon, mutta joutuu odottamaan liian kauan: jonotusongelma

- yksilö hakeutuu hoitoon, mutta sopivia hoitomuotoja ei ole tarjolla tai niiden integraatio ja koordinaatio ovat puutteellisia: saatavunsongelma (luukulta-luukulle pompottelu).

Alikysyntäongelmaan voi ensisijaisesti vaikuttaa terveyskasvatuksella. Saavutettavuusongelmaan voi vaikuttaa palveluverkon kautta, esim. lähipalvelut (terveyskioskit, on-demand perusterveydenhuolto ilman ajanvarausta), matalan kynnyksen palvelut, ja sähköiset palvelut. Myös asiakasmaksuilla on merkitystä palvelujen saavutettavuuteen matalan tulotason sosioekonomisille ryhmille (10). Jonotusongelma on puolestaan usein johtamisongelma, joka liittyy käytettävissä olevaan kapasiteettiin, kysynnän hallintaan ja hoitopolkujen koordinointiin.

Saatavuusongelma riippuu valikoimasta (mitä kaikkea on saatavilla yhdestä palvelupisteestä). Jos valikoima on kapea, joudutaan turvautumaan lähetteisiin, mistä seuraa koordinaatio-ongelmia. Moniongelmaisten kohdalla kysymys on palvelujen integraatiosta henkilötasolla, ts. voidaanko kullekin luoda diagnoosi ja hoitosuunnitelma, jossa tuodaan yhteen kaikki olennaiset ongelmat ja niihin erikoistuneet palvelutuottajat.

Sote-asiantuntijaryhmä antoi syyskuussa 2017 yhteisen lausunnon ehdotettuun valinnanvapauteen liittyvistä ongelmista (11). Jäljempänä esitetään kirjoittajien kannanotot STM:n 3.11.2017 päivätystä valinnanvapauslakiluonnoksesta esittämiin kysymyksiin.

\section{VOIDAANKO EHDOTETULLA VALINNANVAPAUSLAILLA OSALTAAN KAVENTAA VÄESTÖN TERVEYS- JA HYVINVOINTIEROJA SEKÄ PARANTAA PALVELUJEN YHDENVERTAISTA SAATAVUUTTA}

Sote-uudistusta arvioitaessa on syytä muistaa, että erityisesti Suomen terveyspalvelujärjestelmä on kansainvälisen mittapuun mukaan poikkeuksellisen kustannustehokas: saamme suhteellisen vähällä rahalla suhteellisen paljon terveyttä ja hyvinvointia (12-14). Ongelmana on kuitenkin se, että joidenkin palvelujen saatavuus on huono ja että palvelut - erityisesti avoterveydenhuolto - kohdentuvat liiaksi jo etukäteen paremmassa asemassa oleville (15-17).

Palvelujen yhdenvertaisen saatavuuden kannalta järjestämisvastuussa olevalla maakunnalla tulee olla sekä riittävät taloudelliset voimavarat että riittävä tuotantokapasiteetti (henkilöstö, tilat, laitteet, tietojärjestelmät) tarvittavien palve- 
lujen tuottamiseen. Lainsäädännön tulee lisäksi pystyä varmistamaan sekä palvelujen tarveperusteinen saatavuus että palvelujen kohdistuminen niin, että väestön terveys- ja sosiaaliset hyvinvointierot kaventuvat. Tämä tarkoittaa käytännössä resurssien suuntaamista nykyistä selvemmin pienituloisimmille, vähemmän koulutetuille ja huono-osaisille. Erityisesti matalaan sosioekonomiseen asemaan usein liittyvät moninaiset palvelutarpeet tulisi huomioida ja resursseja suunnata enenevästi niille alueille, missä kuolleisuuden taso ja tuloryhmien välinen eriarvoisuus ovat suurimpia (18). Näiden tavoitteiden tulee toteutua paitsi kunkin maakunnan sisällä myös koko valtakunnan tasolla. Vaarana on, että erityisesti esitysluonnoksessa ehdotettu asiakassetelin käyttö ja jossain määrin myös henkilökohtainen budjetti suuntaavat sote-voimavaroja jo etukäteen paremmassa asemassa oleville, mikä estää maakuntien pyrkimyksiä ohjata resurssien käyttöä terveys- ja sosiaalisten hyvinvointierojen kaventamiseksi.

Yksi sote-uudistuksen lähtötavoitteista on ollut kaventaa terveys- ja sosiaalisia hyvinvointieroja parantamalla palvelujen saatavuutta. Valinnanvapaus voi Ruotsin kokemusten perusteella vahvistaa perusterveydenhuollon palveluita. Kilpailun vaikutuksista palvelujen parempaan saatavuuteen on muualtakin näyttöä (19-21). Pohjoismaissa (Ruotsi ja Norja) valinnanvapaus perustason palveluiden osalta on kuitenkin johtanut palvelujen parantumiseen nimenomaan kasvukeskuksissa, mutta parantumista ei ole samassa määrin tapahtunut haja-asutusalueilla. Vaarana on alueellisten erojen kasvaminen (22). Resurssien (esim. perusterveydenhuollon lääkäreiden) kohdentumista on Suomeen ehdotetussa järjestelmässä hyvin vaikea ohjata. Ruotsissa valinnanvapaus on lisännyt suhteellisen terveiden potilaiden palveluiden käyttöä, mikä viittaa siihen, ettei valinnanvapaus ole ainakaan kaventanut terveyseroja Ruotsissa (23). Valinnanvapaudella voi olla muita terveys- tai sosiaalipalvelujärjestelmän kannalta myönteisiä vaikutuksia (24), mutta tämä Ruotsista saatu näyttö ei tue sitä, että se auttaisi terveys- ja sosiaalisten hyvinvointierojen kaventamisessa.

Palvelujen saavutettavuuden ja saatavuuden välillä on ristiriita: Jos saavutettavuutta yritetään korjata tiheällä lähipalveluverkolla, niissä ei voi olla kovin runsasta valikoimaa, mikä puolestaan heikentää saatavuutta, ellei samalla kehitetä erityisiä käytänteitä sujuvasta jatkohoitoon ohjauksesta. Sote -keskusten niukka kapitaatiokorvaus ja siitä seuraava suppea palveluvalikoima voi edistää saavutettavuutta, mutta haitata saatavuutta ja integraatiota $(25,26)$. On kyseenalaista, miten valinnanvapaus voisi edistää em. tekijöitä. Lainsäädännön avulla ei tule mikromanageerata tämä tason ilmiöitä, vaan sen tulisi tarjota palvelutuottajille kannustimia kehittää ratkaisuja näihin ongelmiin. Kannustimet puolestaan edellyttävät täsmällistä tietoa väestön terveydentilasta ja palvelujen käytöstä, sekä ennustavaa analytiikkaa riskiryhmistä.

Palveluiden uudistamisessa alueellisen ja väestöryhmien välisen eriarvoisuuden kaventaminen edellyttävät, että sosiaali- ja terveydenhuollon integraatiosta huolehditaan. Paljon palveluita käyttävien ryhmään kuuluu jo etukäteen haavoittuvassa asemassa olevista muun muassa lastensuojelun, päihdepalveluiden, vammaispalveluiden ja kehitysvammaispalveluiden sekä psykiatrian erikoissairaanhoidon asiakkaita (27). Kyseessä ovat useimmiten sosiaalihuollon palveluiden piirissä olevat ryhmät, ja kuitenkin sosiaalihuollon integraatio toteutuu esitetyssä mallissa hankalimmin.

Työterveyshuolto on edelleen jokseenkin kokonaan reformin ulkopuolella, mikä on selkeä ongelma palveluiden yhdenvertaisen saatavuuden sekä terveys- ja sosiaalisten hyvinvointierojen kaventamisen kannalta. Tällä hetkellä 1,8 miljoona suomalaista saa perusterveydenhuollon palvelunsa työterveyshuollon kautta, joten sen jättäminen reformikokonaisuuden ulkopuolelle vähentää selvästi yhdenvertaisen ja kokonaisuudessaan kustannustehokkaan sekä toimintavarman palvelujärjestelmän kehittymistä. Työterveyshuolto ei myöskään integroidu sosiaalipalveluihin.

Palvelujen yhdenvertaisen saatavuuden kannalta on keskeistä, että palvelu- ja hoitokäytännöt sekä hoito- ja palveluketjut ovat eri alueilla yhdenmukaisia ja tuottavat suositusten mukaisia laadukkaita palveluja. Monituottajamallissa - ja potilaiden ja asiakkaiden käyttäessä omaa harkintaansa palvelujen suhteen - on hyvin vaikea varmistaa, että eri alueilla ja eri asiakkaille/potilaille tarjotut palvelut muodostavat vaikuttavan kokonaisuuden. Tämä aiheuttaa riskin sille, että merkittävä joukko asiakkaita tai potilaita ei saa 
asianmukaisia palveluja, mikä helposti johtaa terveys- ja sosiaalisten hyvinvointierojen kasvuun.

Tarveperusteisten palveluiden yhdenvertaisen saatavuuden kannalta kriittistä on se, miten valinnanvapaus ohjaa palveluiden käyttöä. Vaarana on, että sellaisten asiakkaiden ja potilaiden, jotka eivät pysty valinnanvapautta käyttämään, palvelutarpeet eivät tule yhdenvertaisesti tyydytetyksi valinnanvapautta hyödyntävien henkilöiden kanssa. Tilanne on erityisen haastava, jos valinnanvapauden toteuttaminen priorisoidaan ja sosiaali- ja terveydenhuollon kulujen kasvua samalla kontrolloidaan tiukalla kehysbudjetoinnilla. Tällöin riskinä on, että muiden palvelujen rahoitusta ja resursointia joudutaan leikkaamaan. Henkilön kyky ja taito käyttää palveluja ei voi eikä saa olla peruste sille, saako henkilö ja miten hän saa palveluja.

\section{ANTAAKO LAKILUONNOS ASIAKKAALLE RIITTÄVÄT MAHDOLLISUUDET HAKEUTUA ASIAKKAAN OMAAN TILANTEESEEN SOPIVAAN PALVELUUN}

Palvelujen asiakaslähtöisyyden lisääminen on keskeinen tavoite eurooppalaisissa sosiaali- ja terveydenhuollon järjestelmissä (28). Ei kuitenkaan ole olemassa mitään yleisesti hyväksyttyä ja validoitua tapaa arvioida palvelujärjestelmän asiakaslähtöisyyttä (29-32). Tämä juontaa asiakaslähtöisyyden käsitteen epäselkeydestä, sillä se ei lopulta kerro asiakkaan asemasta ja oikeuksista tai osallisuuden mahdollisuuksista palveluissa $(31,32)$. Käsite jää tyypillisesti hyvää tarkoittavaksi tavoitekieliseksi mantraksi. Valinnanvapauden ajatuksellisena lähtökohtana on, että asiakas/ potilas ymmärtää sekä oman palvelutarpeensa että tuottajien tarjonnan ja laadun ja osaa sen perusteella valita "sopivat palvelut". Historiallisesti tarkastellen tämä lähtökohta ei ole toiminut. Esimerkiksi lääkärinammatin harjoittamisen rajoitusten perustana on ollut tarve varmistaa potilasturvallisuus ja suojata potilaita palvelujaan markkinoivilta "puoskareilta". Lääkkeiden ja lääkintälaitteiden myyntilupasäännöksillä on taas rajoitettu näiden tuotteiden markkinointia suoraan kuluttajille.

Terveystaloustieteessä terveydenhuollon markkinaehtoistamisen ongelmaksi onkin aina nähty tiedollinen epäsuhta palvelun käyttäjän sekä palvelun tarjoajan välillä (33). Toisin sanoen palvelujen tarjoaja pystyy lisäämään palvelujen tarvetta ja käyttöä, eikä palvelun käyttäjä osaa valita itselleen aidosti hyödyllisiä palveluja. Sama pätee erityisesti vaativimpiin sosiaalipalveluihin ja tilanteisiin, joissa asiakkaalla on useita palvelutarpeita. Tätä tiedollista epäsuhtaa (information asymmetry) ei valinnanvapauslaki poista, mutta se kärjistää eri ryhmien välisiä eroja järjestelmässä tarvittavassa palvelu(kuluttaja)osaamisessa, jollei samalla palveluohjausta ja tiedonsaantia palvelujen laadusta lisätä voimakkaasti.

Keskeinen ongelma valinnanvapauden toteuttamisessa onkin, määrittyykö "sopiva palvelu" subjektiivisesti vai objektiivisesti. Potilaan ja asiakkaan kokemus saamastaan hoidosta/palvelusta on tärkeä esimerkiksi kroonisten sairauksien ehkäisemisen ja hoitamisen sekä päihdehuollon hoitoon sitoutumisen kannalta. Terveydenhuollossa on kuitenkin erityisesti erikoissairaanhoidossa kokonaisuuksia, joissa potilaan kokemus ei ole niin määrittävä hoidon onnistumisen kannalta. Hyvän hoidon lopputulos voi määräytyä silloin helposti sellaisista ammattilaisen/tuottajan ominaisuuksista, joita asiakas ei lainkaan hahmota valintaa tehdessään. Sama pätee vaativiin sosiaalipalveluihin, kuten päihdehoitoon ja lastensuojeluun. Kevyimmissä (suoritetyyppisissä) sosiaalipalveluissa, kuten vanhusten kotipalveluissa, on saatu hyviä kokemuksia palvelusetelillä toteutetusta valinnanvapaudesta.

Valinnanvapauslakiin sisältyy hallinnollisesti raskaita ja käytännössä monimutkaisesti toteutettavia säännöksiä palvelutarpeen arvioinnista. Toisaalta lakiin sisältyy runsaasti säännöksiä potilaan/asiakkaan toiveiden huomioimisesta, jotka saattavat edistää myös ns. palvelushoppailua. Ei ole näyttöön perustuvaa aineistoa sen suhteen, että valinnanvapauslaissa esitetty palvelutarpeen arvioinnin malli toimisi asiakasta/potilasta tyydyttävällä tai kansanterveyttä tai sosiaalista hyvinvointia hyödyttävällä tavalla pidemmässä tarkastelussa.

Valinnanvapausmalli soveltuu parhaiten palvelutarpeisiin, jotka ovat selkeitä ja yksi asia kerrallaan hoidettavia. Usein palvelutarpeet kuitenkin kimppuuntuvat yhteen sekä sosiaali- että terveyspalveluja edellyttäväksi tai useampia terveys- tai sosiaalipalveluja vaativiksi. Näissä useiden tarpeiden tilanteissa asiakkaiden/potilaiden ohjautuminen tarpeenmukaisesti on monimutkaisessa palveluvalikossa vaikeaa. Asiakkaiden tilanteet myös muuttuvat nopeasti, mihin valinnanvapauden mahdollisuudet eivät ehdi 
aina realisoitua. Valinnanvapauden käyttäminen vaatii joka tapauksessa runsaasti palveluohjausta, mikä myös lisää resurssien tarvetta ja mallin kustannuksia. Integraatio monimutkaistuu, kun on useita erillisiä toimijoita. Esimerkiksi sosiaalipalvelujen tuottajan edellytykset havaita palvelutarve riippuvat terveydenhuollon tuottajasta, jolla puolestaan ei aina ole tähän tarvittavaa asiantuntemusta.

Lakiesityksen yhtenä lähtökohtana on luoda markkinoita, joilla maakunnan asukkailla olisi mahdollisuus valita suoran valinnan, asiakassetelien ja henkilökohtaisen budjetin palvelutuottajien välillä omaan tilanteeseensa sopiva palvelu. Jotta valinta olisi yleensä mahdollinen, maakunnan olisi varmistettava, että jokaista valinnan piirissä olevaa palvelua tarjoisi vähintään kaksi tuottajaa. Tuottajia olisi hyvä olla enemmänkin, jotta yksi tuottaja ei voisi saada määräävää markkina-asemaa. Määräävä markkina-asema voi vallita myös maakunnan jollakin osa-alueella. Toisaalta, mitä enemmän palvelun tarjoajia on, sitä enemmän niiden vertailu vaatii asiakkailta tietoa ja osaamista, jolloin heikommassa asemassa olevat jäävät myös palveluiden käyttäjinä heikompaan asemaan. Sosiaali- ja terveydenhuollon johtajilla ei ole kokemusta elinkeinopoliittisessa tarkoituksessa tehdystä markkinoiden luomisesta. Esimerkiksi Ruotsissa maakäräjillä on lain perusteella vastuu vain perusterveydenhuollon markkinoiden ylläpitämisestä. Tämänkin tehtävä on osoittautunut vaikeaksi, eikä esimerkiksi terveyspoliittisten tavoitteiden mukaisten korvausmallien laatimisessa ole täysin onnistuttu. Lisäksi meiltä puuttuu toistaiseksi vielä pitkän aikaa riittävä tietoperusta palveluiden tosiasialliseen vertailuun.

\section{JOS ASIAKKAALLA ON LAAJA-ALAISIA PALVELU- TARPEITA, TOTEUTUUKO LAKILUONNOKSEN PERUSTEELLA ASIAKKAAN MAHDOLLISUUS SAADA TARPEEN MUKAISELLA TAVALLA YHTEEN SOVITETTUJA PALVELUJA?}

Kysymyksenasetteluun sisältyy asiakasnäkökulmissa esiintyviä hankalia käsitteitä, kuten mitä tarkoitetaan asiakkaan laaja-alaisilla palveluilla, milloin asiakas luetaan laaja-alaisesti palveluja tarvitsevaksi ja mitä tämä ajateltu erityisyys palveluissa tuottaa. Siihen sisältyy implisiittisesti myös runsaasti viljelty ilmaisu "paljon palveluja tarvitsevista asiakkaista", jotka nähdään usein järjestelmän ongelmina, ei niinkään ihmisinä, joihin palveluissa tulisi eniten investoida. Heidät saatetaan myös luokittaa lähinnä sosiaalihuollon palveluita tarvitseviksi osaamatta tarttua heidän kokonaistarpeisiinsa. Kun palvelutarpeita on samanaikaisesti monia, mitä nämä asiakkaat käytännössä valitsevat.

Sote-uudistuksen alkuperäisenä tavoitteena oli parantaa palvelujen vaikuttavuutta integroimalla palvelukokonaisuuksia. Kuten Duodecimlehden pääkirjoituksessa syksyllä 2017 todetaan: "...peruspalveluita koskeva valinnanvapaus rikkoo toiminnan integraatiotavoitteen mahdollisimman täydellisesti. Tuhoa täydennetään vielä pelkkiä peruspalveluita koskevalla kapitaatiolla, jossa korvaukset määräytyvät listautuneiden potilaiden tai asiakkaiden määrän mukaan, jolloin palveluntuottajien kannusteet vaihtuvat kesken hoitoketjun. Omien kustannusten välttely alkaa kukoistaa ennennäkemättömällä tavalla, kun toimijat alkavat siirrellä hoitovastuita toisilleen omaa taloudellista hyötyään tavoitellen. Suurin hyötyjäryhmä ovat riitoja ja vastuita selvittävät juristit. Potilaat joutuvat pahenevan pallottelun kohteeksi, ja Suomen kansantalous kantaa suurimmat tappiot..." (34).

Valinnanvapauslakiin esitetty asiakassuunnitelma voi joltain osin ja erillisryhmien osalta parantaa palvelujen yhteen sovittamista. Asiakassuunnitelman laatiminen on annettu pääosin maakunnan liikelaitoksen ja sote-keskuksen tehtäväksi. Jotta potilaan hoito toteutuisi asianmukaisesti, tulee hoitoa toteuttavan sote-keskuksen olla hoidon edetessä jatkuvasti yhteydessä liikelaitokseen, jotta asiakassuunnitelma päivittyy vastaamaan potilaan hoidon ja huollon tarvetta. Eri tilanteissa suunnitelmat myös rakentuvat eri tavoin, esimerkiksi sosiaalihuollon palveluiden osalta vastuu kuuluu kokonaan maakunnan liikelaitokselle. Käytännön toiminnassa, varsinkin monia palveluita sisältävien palvelusuunnitelmien vastuusuhteet tulevat olemaan hankalia organisoida.

Valinnanvapaus voisi periaatteessa edistää integraatiota, jos markkinoille syntyy integroitujen palvelukokonaisuuksia ja jos potilaat ja asiakkaat suosivat niitä valinnoissaan. Esitetty asiakassetelimalli heikentää suuresti näitä mahdollisuuksia, sillä se pilkkoo palvelut erillisiin tuotteisiin. Asiakassetelin perusteella palveluja tuottava toimija joutuu todennäköisesti toistuvasti neu- 
vottelemaan asiakassetelin myöntäjän kanssa esimerkiksi asiakkaan/potilaan tarvitsemista tutkimuksista ja/tai palvelun ja hoidon intensiteetistä. Menettely on byrokraattinen ja paljon lisäkustannuksia aiheuttava sekä käytännölle vieras terveydenhuollossa, Myös asiakassuunnitelman juridinen velvoittavuus on hyvin epäselvä, koska sosiaali- ja terveydenhuollossa tilanteet voivat muuttua nopeasti ja suunnitelmatasoisina ne eivät rakennu varsinaisina velvoittavina palvelupäätöksinä

Paljon palveluja tarvitsevalla asiakasryhmällä, erityisesti ikääntyneillä, on samanaikaisesti sosiaali- ja terveydenhuollon palveluja. Asiakassuunnitelmalla pyritään korvaamaan puuttuvaa integraatiota eri palveluntuottajien välillä, mutta asetetut tavoitteet vaikuttavat epärealistisen suurilta. Järjestelmien tasolla toivottu integraatio pyritään tuottamaan järjestelmän sijasta yksilötasolla.

Integraation mahdollisuuksia vaikeutta merkittävästi myös se, että sosiaalihuollon palvelut eivät rakennu terveydenhuollon rinnalle palvelujärjestelmässä ja niiden rooli näyttäytyy vähemmän merkittävinä lähinnä terveyskeskuksia muistuttavissa sote-keskuksissa. Eroja tuottaa myös sosiaali- ja terveyspalveluiden erilainen lakisääteinen toimintalogiikka, jossa osa sosiaalipalveluista perustuu hallintopäätöksiin. Tätä on pyritty ratkaisemaan tuottamalla sosiaalihuollon palvelut sote-keskuksiin maakuntien liikelaitosten jalkautuvien työntekijöiden avulla. Malli edellyttää kuitenkin, että sosiaalihuollon palveluja tarvitsevien asiakkaiden saatavissa sotekeskuksissa on kokoaikaiset ja pysyvät palvelut, vaikka ne organisoitaisiin hallinnollisesti maakunnan toimesta. Esitetyssä sosiaalihuollon palveluiden tuottamisessa on implisiittisesti esillä myös henkilöstön vähäisyys, kun terveydenhuollon henkilöstön osalta vastaavaa ei esiinny.

Henkilökohtainen budjetti voi periaatteessa luoda mahdollisuuksia palveluintegraatioon. Mallin käytöstä on kuitenkin melko vähän kokemusta. Malli on tarkoitus säätää subjektiiviseksi oikeudeksi, jolloin siihen liittyy samoja edellä kuvattuja ongelmia kuin asiakasseteliin. On epäselvää, voivatko maakunnat kohdentaa resursseja niitä eniten tarvitseville, jotka eivät välttämättä osaa vaatia ja räätälöidä itselleen henkilökohtaisia budjetteja. Henkilökohtaisen budjetin käyttö edellyttää runsasta palveluoh- jausta, mikä on tarpeen huomioida kokonaisuuden kustannusrakenteessa.

\section{ANTAAKO ESITYS MAAKUNNILLE RIITTÄVÄT EDELLYTYKSET JÄRJESTÄMISVASTUUN TOTEUTTAMISEEN}

Jotta maakunta voisi hallita taloudellisia resurssejaan eli tuottaa järjestämisvelvollisuuteen kuuluvat palvelut valtion siihen osoittaman määrärahan puitteissa, tulee sillä olla tieto alueensa väestön sairastavuudesta ja hyvinvoinnin tilasta sekä väestön tarvitsemista palveluista ja niiden kustannuksista. Jos suoran valinnan palveluista maksettava kapitaatiokorvaus jää liian alhaiseksi, ei palveluille löydy tuottajia. Myös kannustimet laadukkaaseen toimintaan ovat vähäiset (35). Jos suoriteperusteisesti korvattujen tuotteiden (esim. asiakassetelituotteet) määrä tai korvaus nousee suureksi, ylittyvät maakunnan käyttöön osoitetut määrärahat. Mikäli korvaukset huomioivat huonosti potilaan kustannusriskin, sairaampien ja hoitoa eniten tarvitsevien voi olla vaikeampi saada palvelua kilpailullisilta tuottajilta (36). Oikean tasapainon löytyminen kapitaatiokorvauksen ja suoriteperusteisten korvausten välille sekä asiakassetelien käytölle edellyttää usean vuoden talousarviosyklin läpikäymistä. Muussa tapauksessa rahoituksen yhdenvertainen kohdistuminen väestön palvelutarpeisiin ja rahoituksen riittävyys on arpapeliä.

Uudistuksen vaikutukset hyvinvointi- ja terveyseroihin ja palveluiden saatavuuteen voivat riippua keskeisesti rahoituskorvauksista. Maakuntien ja tuottajien rahoituskorvaukset tulisi suunnitella sellaiseksi, että ne kannustavat tarjoamaan palveluita niitä eniten tarvitseville. Korvausperusteilla on havaittu olevan vaikutusta myös siihen, mille hoito- tai maantieteellisille alueille tuottajat sijoittuvat (37).

Riskinä järjestämisvastuun toteuttamisen kannalta on myös uudistuksen aiheuttama hallitsematon henkilöstön liikkuvuus maakunnan liikelaitoksen ja yksityisten tuottajien välillä. Jos yksityisten toimijoiden palvelukseen siirtyy merkittävä määrä esim. erikoissairaanhoidon päivystystä varten tarvittavaa henkilöstöä, vaarantuu päivystyspalvelujen saatavuus varsinkin pienemmissä maakunnissa. Erityisen varovainen pitäisikin olla nopeissa muutoksissa sellaisten palvelujen osalta, joissa yhteiskunnan sisäinen turvallisuus edellyttää 7/24 -palveluja ja joihin liittyy viranomaistoimintaa $(\mathrm{mm}$. erikoissairaanhoidon päi- 
vystys, sosiaalipäivystys ja lastensuojelu). Hallitsematon henkilöstön siirtyminen yksityisten tuottajien palvelukseen voi myös vaarantaa sotehenkilöstön koulutusta ja siten palveluiden laatua pidemmällä aikavälillä.

Maakunnan ohjaus eri palvelutuottajiin tapahtuisi esityksen perusteella monimutkaisena näyttäytyvänä liikelaitoksen sopimusohjauksena ja tuottajien valintana sekä heidän korvausten määrittämisenä. On toistaiseksi erittäin epäselvää, miten tällainen malli tosiasiallisesti toimii. Tosiasiallisesti maakunnat eivät voi valita alueensa palveluntuottajia, vaan hyväksymismenettely koskee kaikkia kriteerit ja ehdot täyttäviä palveluntuottajiksi ilmoittautuneita. Maakuntien velvoite asiakassetelin laajamittaiseen käyttöön hankaloittaa alueellisesti tarkoituksenmukaisten ratkaisujen hakemista. Pykälän 24 yksityiskohtaisiin perusteluihin vedoten maakunta ja sen liikelaitos voi rajoittaa setelin käyttöönottoa useaan lueteltuun perusteeseen vedoten. Kieltäytyminen asiakassetelin antamisesta ratkaistaisiin kuitenkin lopulta hallintoriitana hallintotuomioistuimessa.

Integraation ja koordinaation toteuttaminen maakunnan tehtävänä tulee esitetyssä mallissa olemaan todella vaikeaa. Jos asiakasseteli on suoriteperustainen, ts. sillä maksetaan erityinen toimenpide, asiakas/potilaskohtaiselle integraatiolle ei ole taloudellisia kannustimia. Asiakassetelin tulisi kattaa kokonainen palveluprosessi tai hoitoepisodi. Sote-kokonaisuudesta muodostuu esityksen perusteella hyvin hajanainen ja vaikeasti johdettava. Parhaimmillaankin vaatii useita vuosia ennen kuin alueellisesti on muodostunut riittävä kokemus järjestelmän ohjauksesta. Markkinat rakentuvat kuitenkin nopeasti ja markkinoilla toimiville valinnanvapauden palvelujen tuottajille muodostuu helposti oma agendansa, jonka ytimessä ei välttämättä ole alueen väestön terveyden ja sosiaalisen hyvinvoinnin lisääminen. Todellisuudessa syntyvät sote-keskusten markkinat tulevat jakautumaan suurten (ylikansallisten) yritysten kesken, sillä pienet yritykset tai järjestöt eivät todennäköisesti kykene tuottamaan riittävän monipuolisia ja laaja-alaisia palvelukokonaisuuksia.

Lakiesityksen yleisperusteluissa eikä sen vaikutusarvioissa ei ole riittävästi arvioitu sitä, miten paljon resursseja toimivien markkinoiden aikaansaaminen ja ylläpitäminen sekä tuottaja- monopolien syntymisen ehkäiseminen edellyttävät investointien, valvonnan ja tuottajakorvausten muodossa. Lisäksi on otettava huomioon, että markkinoiden jakautuminen jopa satoihin tuotesegmentteihin, seutukuntakohtaisiin osamarkkinoihin ja moniin erilaisiin tuottajien rahoitus-, ohjaus-, sääntely- ja valvontamekanismeihin sekä tieto-, oikeusturva- ym. järjestelmiin nostaa erityisesti maakunnan transaktiokustannuksia merkittävästi (38).

Lisäkustannuksia aiheutuu myös tuottajien kilpavarustelusta esimerkiksi palvelupisteiden sijainnissa, teknologiassa ja lisäpalveluissa sekä avainosaajien rekrytoinnissa $(39,40)$. Yhdenvertaisten palveluiden tarjoaminen edellyttää sitä, että myös maakunta osallistuu kilpavarusteluun. Tämä pätee erityisesti niihin alueisiin, joille ei synny yksityistä tuotantoa.

\section{JOHTOPÄÄTÖKSET}

Terveys- ja sosiaalisten hyvinvointierojen kaventamiselle on selvä tarve. Valinnanvapauden terveys- ja hyvinvointieroja pienentävästä vaikutuksesta ei kuitenkaan ole tutkimuksellista näyttöä. Valinnanvapauslaki ei varmista resurssien yhdenvertaista kohdentumista ja voi jopa lisätä terveysja sosiaalisen hyvinvoinnin eroja.

Ehdotettu valinnanvapaus voi parantaa niiden sosiaali- ja terveyspalveluja tarvitsevien henkilöiden asemaa, joiden toimintakyky on riittävä uudistuvan järjestelmän tuomien mahdollisuuksien hahmottamiseksi. Se ei kuitenkaan toteudu sosiaali- ja terveydenhuollon integraation kannalta yhdenmukaisella tavalla eikä ulotu sosiaalipalveluihin. Valinnanvapauslaki luo asiakkaan kannalta monimutkaisen palveluiden järjestelmän, jossa palveluketjut (ainakin useampia palveluita tarvitsevilla) katkeavat. Se voi jopa heikentää sellaisten potilaiden/asiakkaiden palvelujen saatavuutta, jotka eivät pysty valinnanvapautta käyttämään.

Valinnanvapauslaki todennäköisesti parantaa perustason terveyspalvelujen saatavuutta, mutta alueellisesti vaikutukset voivat olla erilaisia ja jossain jopa palvelujen saatavuutta huonontavia. Valinnanvapauden kautta lisääntynyt resurssitarve voi myös heikentää sellaisten palvelujen resursseja ja sitä kautta myös saatavuutta, joita valinnanvapaus ei koske (päivystys, vaativa sairaanhoito) ja merkitä "käänteistä priorisointia". Tällöin yhteiskunnan resursseista kohdennetaan 
aiempaa suurempi osa kiireettömään hoitoon.

Valinnanvapauslaissa esitetty palveluihin hakeutumisen malli on uusi eikä näyttöä sen vaikuttavuudesta ole sen paremmin kansanterveyden ja kansallisen sosiaalisen hyvinvoinnin rakentumisen kuin yksilöiden edun kannalta. Malli toimii parhaiten selkeissä, yhden palvelutarpeen tilanteissa, mutta se kohtaa vaikeuksia useampiin samanaikaisiin tarpeisiin vastaamisessa. Malli edellyttää lisäksi laajaa ja resursseja edellyttävää palveluohjauksen organisoimista, koska palvelujen tarjoajan ja palvelujen käyttäjän välillä on tiedollinen epäsuhta, mikä helposti johtaa palvelun käyttäjän kannalta epätarkoituksenmukaisten ja vieraita intressejä toteuttavien palvelujen valintaan.

Valinnanvapauden yhtenä tavoitteena on parantaa asiakastyytyväisyyttä, mutta asiakastyytyväisyys on moniulotteisesti määrittyvä suure, eikä ole olemassa luotettavaa menetelmää sen mittaamiseen. Asiakastyytyväisyyteen vaikuttaa lopulta hoidon lopputulos, eikä pelkkä lyhyt asiakaskokemus palvelutapahtumasta ja sen valinnasta.

Valinnanvapautta esitetään parannettavaksi lisäämällä asiakassetelien käyttöä. Sosiaalihuollon suoritetyyppisissä palveluissa on valinnanvapauslain asiakasseteliä vastaavaa palvelusetelijärjestelmää käytetty monin paikoin hyvin tuloksin. Sosiaali- ja terveydenhuollon asiakassetelille kaavaillut uudet käyttökohteet saattavat parantaa niiden asiakkaiden asemaa, jotka ovat riittävän vahvoja ja toimintakykyisiä valitsemaan eri palveluntuottajien välillä. Asiakkaan mahdollisuus saada tarpeen mukaisella tavalla yhteensovitettuja palveluja toteutuu kuitenkin ehdotetussa mallissa pääosin huonosti. Eri palveluntuottajien omat intressit ajavat helposti potilaan ja asiakkaan kokonaisedun ohi.

Lakiesitykseen sisältyvä velvoite asiakassuunnitelman laatimiseen on hallinnollisesti raskas ja vastuusuhteiltaan epäselvä menettely. Asiakassuunnitelmaa on myös käytännössä hyvin vaikea pitää ajan tasalla muuttuvissa tilanteissa. Asiakassuunnitelma ei ole velvoittava, eikä tuota asiakkaalle varsinaisia oikeuksia. Peruspalvelujen puutteellinen integrointi aiheuttaa paljon palveluja tarvitsevalle haasteita selvitä tuottajaviidakossa.

Mielenterveys- ja päihdepalvelujen puute suoran valinnan palveluissa on merkittävä ongelma asiakaan palvelujen yhteensovittamisen kannalta (erityisesti, koska näillä ryhmillä on riski päätyä paljon palveluja käyttäviksi asiakkaiksi) (41). Maakunnan tuottamat sosiaalihuollon palvelut sote-keskuksissa tulisi olla kokoaikaisesti ja pysyvästi asiakkaiden saatavilla

Kokonaisuutena uudistuksen tuloksena syntyvä sosiaali- ja terveydenhuollon järjestelmä on vaikeasti ohjattava. Sopimusohjauksen toimivuudesta Suomessa järjestäjän ja tuottajan välillä ei ole näyttöä nyt kaavaillussa mittakaavassa, eivätkä aikaisemmat kokemukset tällaisesta mallista tue oletusta ohjausmallin tehokkuudesta. Taloudellisesti kestävän tuotantotavan hakemiseen menee kussakin maakunnassa useita budjettikausia. Merkittävät siirrot henkilöstöresursseissa uudistuksen alussa voivat vaarantaa keskeisten toimintojen (kuten päivystys, vanhusten kotipalvelut) järjestämisen.

Maakunnan järjestämisvastuun kannalta on oleellista, että niille annetaan riittävä, tosiasiallinen toimivalta alueensa palvelujärjestelmän rakentamisessa, minkä liian yksityiskohtainen säätäminen voi estää (tästä esimerkkinä ehdotetut suoran valinnan erikoislääkäripalvelut).

Lakiehdotuksen ongelma on, että se yrittää tarjota yleisiä ratkaisuja erityisiin ongelmiin: Joidenkin väestöryhmien alikysyntää yritetään hoitaa palvelutarjontaa lisäämällä. Joidenkin väestöryhmien alikäyttöä yritetään hoitaa resursoimalla kaikkea. Sote -integraatiota tarvitsevien tarpeisiin yritetään vastata integroimalla koko järjestelmä. Silti integraatio jää lopulta toteuttamatta.

\section{LÄHTEET}

(1) Helliwell, J, Layard R, Sachs J. World Happiness Report 2017. Sustainable Development Solutions Network, New York 2017.
(2) Terveyden ja hyvinvoinnin laitos.

Toimeentulotuki 2015. Luettu 13.1.2018. http://www.julkari.fi/bitstream/ handle/10024/131612/Tr19_16.pdf?sequence=4 
(3) Terveyden ja hyvinvoinnin laitos. Lastensuojelu 2015. Luettu 13.1.2018. Helsinki. http://www.julkari.fi/bitstream/ handle/10024/131625/Tr20_16.pdf? sequence=4

(4) Ohisalo M, Saari, J. Kuka seisoo leipäjonossa? Ruoka-apu 2010-luvun Suomessa. Luettu 13.1.2018.

http://www.kaks.fi/sites/default/files/ TutkJulk_83_net.pdf

(5) Tarkiainen L, Martikainen P, Peltonen R, Remes H. Sosiaaliryhmien elinajanodote-erojen kasvu on pääosin pysähtynyt. Suomen Lääkärilehti 2017;9:588-593.

(6) Vauhkonen T, Kallio J, Erola J. Sosiaalisen huono-osaisuuden ylisukupolvisuus Suomes-sa. Yhteiskuntapolitiikka 2017;5:501-512.

(7) Karvonen S, Kestilä L. Nuorten aikuisten syrjäytymisvaaraan liittyvä huono-osaisuus. Kirjassa Vaarama, M, Karvonen S, Kestilä L, Moisio P, Muuri A (toim.): Suomalaisten hyvinvointi. Terveyden ja hyvinvoinnin laitos 2014.

(8) Berg N, Huurre T, Kiviruusu O, Aro $\mathrm{H}$. Nuoruusiän huono-osaisuus ja sen kasautumisen yhteys kuolleisuuteen. Seurantatutkimus 16-vuotiaista nuorista. Sosiaalilääketieteellinen aikakauslehti 2011;48:168-181.

(9) Nordic Social Statistical Committee Nososco. Social Protection in the Nordic pert 2013/2014 - Scope, expenditure and financing. Luettu 13.1.2018.

http://norden.diva-portal.org/smash/get/ diva2:882555/FULLTEXT01.pdf

(10) Expert Panel of Effective ways of Investing in Health. Access to health services in the European Union. Luettu 13.1.2018. https://ec.europa.eu/health/expert_panel/sites/ expertpanel/files/015_access_healthservices_ en.pdf

(11) Sosiaali- ja terveysministeriön soteasiantuntijaryhmä. Lausunto esitysluonnoksesta laiksi valinnanvapaudesta sosiaali- ja terveydenhuollossa. Luettu 28.1.2018. https://drive.google.com/file/d/0B7f3lhG6hNn DZDINSC1UNFk3di1UeUphaEd5ZUFjcGpW NFJr/view

(12) Euroopan komissio. State of health in the EU - Suomi - Maan terveysprofilili 2017. Luettu 13.1.2018.

https://ec.europa.eu/health/sites/health/files/state/ docs/chp_fi_finnish.pdf

(13) OECD. Health at a glance - How does Finland compare? OECD 2015, 1-2. Luettu 28.1.2019. https://www.oecd.org/finland/Health-at-aGlance-2015-Key-Findings-FINLAND.pdf

(14) Medin, E., Häkkinen, U., Linna, M., Anthun, K. S., Kittelsen, S. A. C., Rehnberg, C., on behalf of the EuroHOPE study group. International hospital productivity comparison: experiences from the Nordic countries. Health Policy 2013, $112,80-87$.

https://doi.org/10.1016/j.healthpol.2013.02.004
(15) Kivimäki T. Suomen terveydenhoitojärjestelmä on EU:n epätasa-arvoisimpia. Luettu 13.1.2018. http://sosiaalivakuutus.fi/suomenterveydenhoitojarjestelma-eun-epatasaarvoisimpia/

(16) Terveyden ja Hyvinvoinnin Laitos. Hoitoonpääsy perusterveydenhuollossa. Luettu 28.1.2018.

https://www.thl.fi/fi/tilastot/tiedonkeruut/ hoitoonpaasy-perusterveydenhuollossa

(17) Terveyden ja Hyvinvoinnin Laitos. Hoitoonpääsy erikoissairaanhoidossa. Luettu 28.1.2018.

https://www.thl.fi/fi/tilastot/tiedonkeruut/ hoitoonpaasy-erikoissairaanhoidossa

(18) Terveyden ja hyvinvoinnin laitos. Kainuun ja Savon pienituloisilla eniten ennenaikaisen kuoleman vuoksi menetettyjä elinvuosia. Luettu 13.1.2018.

https://www.thl.fi/fi/-/kainuun-ja-savonpienituloisilla-eniten-ennenaikaisen-kuolemanvuoksi-menetettyja-elinvuosia

(19) Gaynor, M., Town, R. Competition in Health Care Markets. Handbook of Health Economics, Volume 2. Pauly M, McGuire T, Barros P (toim.). Elsevier 2011, 499-637. https://doi.org/10.3386/w17208

(20) Expert Panel of Effective ways of Investing in Health. Competition among health care providers - Investigating policy options European Union. Luettu 13.1.2018. https:/ec.europa.eu/health/expert_panel/sites/ expertpanel/files/008_competition_healthcare_ providers_en.pdf

(21) Ringard, Å., Hagen, T. P. Are waiting times for hospital admissions affected by patients' choices and mobility? BMC Health Services Research 2011, 11, 170 . https://doi.org/10.1186/1472-6963-11-170

(22) Luotonen N. Valinnanvapaus asukkaan ehdoilla - Suomen edellytykset Ruotsin kokemusten ja kansainvälisen tutkimustiedon valossa. Luettu 13.1.2018. https://www.hanken.fi/sites/default/files/atoms/ files/valinnanvapaus_asukkaan_ehdoilla_hccg. pdf

(23) Burström, B., Burström, K., Nilsson, G., Tomson, G., Whitehead, M., Winblad, U. Equity aspects of the Primary Health Care Choice Reform in Sweden - a scoping review. International Journal for Equity in Health 2017,16:29.

https://doi.org/10.1186/s12939-017-0524-z

(24) Erhola M, Jonsson PM, Pekurinen M, Teperi J. Jonottamatta hoitoon. THL:n aloite perusterveydenhuollon vahvistamiseksi. Terveyden ja Hyvinvoinnin Laitos, Helsinki 2013.

(25) James, B. C., Poulsen, G. P. The case for capitation. Harvard Business Review 2016, 94, 102-134.

(26) Kortelainen, M., Saastamoinen, A., Saxell, T. Kapitaatiomalli korvausmuotona terveydenhuollon tuottajille. Lääkärilehti 2017; 72: 1502-1506. 
(27) Leskelä RL, Komssi V, Sandström S, Pikkujämsä S, Haverinen A, Olli SL, Ylitalo-Katajisto K. Paljon sosiaali- ja terveyspalveluja käyttävät asukkaat Oulussa. Lääkärilehti, 2013;68:31633169.

(28) Expert Panel of Effective ways of Investing in Health. Future EU Agenda on quality of health care with special emphasis on patient safety. Luettu 13.1.2018. https://ec.europa.eu/health/expert_panel/sites/ expertpanel/files/006_safety_quality_of_care_ en.pdf

(29) Expert Panel of Effective ways of Investing in Health. Draft opinion on Benchmark-ing access to health care in the EU. Luettu 13.1.2018. https://ec.europa.eu/health/expert_panel/ sites/expertpanel/files/018_benchmarking_ accesstohealthcare_en.pdf

(30) Fenton JJ1, Jerant AF, Bertakis KD, Franks P. The cost of satisfaction: a national study of patient satisfaction, health care utilization, expenditures, and mortality. Arch Intern Med 2012;172:405-411.

https://doi.org/10.1001/

archinternmed.2011.1662

(31) Coulter A. Measuring what matters to patients. BMJ 356:j816, 2017. https://doi.org/10.1136/bmj.j816

(32) Staniszewska SH, Henderson L. Patients' evaluations of the quality of care: Influencing factors and the importance of engagement. Journal of Advanced Nursing 2005;49:530-537. https://doi.org/10.1111/j.13652648.2004.03326.x

(33) Arrow K: Uncertainty and the Welfare Economics of Medical Care. American Economic Review 1963;53:941-973.

(34) Heikinheimo M, Huttunen J, Kekomäki M, Kontula K, Mustonen P, Raivio K, Rapola J. Ehdotettu valinnanvapausmalli uhkaa palvelujärjestelmämme perusteita. Duodecim 2017;133:1975-1976.

(35) Kortelainen, M., Saastamoinen, A., Saxell, T. Kapitaatiomalli korvausmuotona terveydenhuollon tuottajille. Lääkärilehti 2017; 72: 1502-1506.

(36) James, B. C., Poulsen, G. P. The case for capitation. Harvard Business Review 2016, 94, 102-134.

(37) Anell, A., Dackehag, M., Dietrichson, J. Does risk-adjusted payment influence primary care providers' decision on where to set up practice? Working Paper 2016, Department of Economics, Lund University 2016:2, 1-36.

(38) Lehto J. Sote-markkinat julkisen sääntelyn haasteena. Yhteiskuntapolitiikka 2017;4; 458-467.

(39) Saxell, T. Terveydenhoitopalvelujen kilpailu voi johtaa kilpavarusteluun. VATT Policy Brief 4-2014.
(40) Kessler, D. P., McClellan, M. B. Is Hospital Competition Socially Wasteful? The Quarterly Journal of Economics 2000, 115, 577-615. https://doi.org/10.1162/003355300554863

(41) Leskelä RL, Silander, K, Komssi, V, Koukkula L, Soppela J, Lehtonen L. Paljon Erikoissairaanhoidon palveluita käyttävät potilaat. Suomen lääkärilehti. 2015;70:2865-2872.

LASSE LEHTONEN

professori, hallintoylilääkäri

Helsingin yliopisto ja HUS

Heikki Hillamo

professori, Helsingin yliopisto

Marina ERHola

ylijohtaja, Terveyden ja hyvinvoinnin laitos

Pentti ArajÄrvi

professori emeritus, Helsingin yliopisto

Jussi Huttunen

professori, pääjobtaja (eläkkeellä), Terveyden ja hyvinvoinnin laitos

Aulikki Kananoja

ylisosiaalineuvos (eläkkeellä). Helsingin kaupunki

MartTI КекомÄKI

professori emeritus, Helsingin yliopisto

Anneli Pohjola

professori, Lapin yliopisto

Hanna TAinio

varatoimitusjobtaja, Suomen Kuntaliitto

Paul LillRank

professori, Aalto-yliopisto

TANJa SAXEll

erikoistutkija,Valtion taloudellinen tutkimuskeskus

Katarinna Silander

tutkimusjohtaja, Aalto-yliopisto

Pirkko Vartiainen

professori Vaasan yliopisto

Tämä kirjoitus perustuu STM:n sote-asiantuntijaryhmän jäsenten valinnanvapauslain esitysluonnoksesta antamiin lausuntoihin. 